\title{
Application of serial tests for Mycobacterium tuberculosis detection to active lung tuberculosis cases in Indonesia
}

\author{
Nastiti Intan Permata Sari ${ }^{1,3^{*}} \mathbb{0}$, Ni Made Mertaniasih ${ }^{2,3^{*}}$, Soedarsono ${ }^{4}$ and Fumito Maruyama ${ }^{5}$
}

\begin{abstract}
Objective: Rapid detection and accurate diagnosis are very important in managing active tuberculosis because they provide an advantage in preventing further disease transmission. In accordance with the recommendation of the World Health Organization, the Indonesian Tuberculosis Control Program uses the acid fast bacilli (AFB) smear and Chest X-ray methods as the primary methods for detecting tuberculosis, especially in new cases of suspected tuberculosis. The genus Mycobacterium has many species, strains, and variants, and their natural differences may affect the clinical outcome of the diseases they induce. The purpose of this study was to assess different tuberculosis detection methods as part of serial tests and determine the best diagnostic approach for detecting active lung tuberculosis in Indonesia.

Results: This study used clinical samples from tuberculosis patients and assessed them using a series of tests, aiming to increase the sensitivity of active tuberculosis detection. Some samples that yielded negative results in the AFB smear test were detected as positive for Mycobacterium tuberculosis using the nucleic acid amplification test, with a sensitivity of $83.1 \%$. Additionally, nucleic acid amplification also detected positive results among samples assessed as M. tuberculosis-negative using the culture method, this method yielded the same results as the Gene Xpert test.
\end{abstract}

Keywords: Acid fast bacilli, Gene Xpert, Culture method, PCR method, Pulmonary tuberculosis, Serial tests

\section{Introduction}

Tuberculosis (TB) is a major global health problem; this disease has caused more deaths than any other infectious disease over the last 200 years [1]. The number of TB deaths remains unacceptably high. To combat this, a timely diagnosis and the application of appropriate treatment are required [2]. TB infection is caused by members of the Mycobacterium tuberculosis Complex (MTBC), which is the major group responsible for human pulmonary

\footnotetext{
*Correspondence: nastitipermata@gmail.com;

nmademertaniasih@gmail.com

${ }^{1}$ Doctoral Program of Medical Science, Faculty of Medicine,

Universitas Airlangga, Jl. Mayjen. Prof. Dr. Moestopo No. 47,

Surabaya 60131, Indonesia

${ }^{2}$ Department of Clinical Microbiology, Faculty of Medicine,

Universitas Airlangga, Jl. Mayjen. Prof. Dr. Moestopo No. 47,

Surabaya 60131, Indonesia

${ }^{3}$ Laboratory of Tuberculosis, Institute of Tropical Disease, Universitas

Airlangga, Kampus C, Jl. Mulyorejo, Surabaya 60115, Indonesia

Full list of author information is available at the end of the article
}

infections. This group is composed of anaerobic, acid-fast, slow-growing bacteria, and it can be difficult to determine the species responsible for specific TB cases [3]. TB usually appears several years after infection, often when the immune system function is decreased by some other cause [4]. The transmission of TB occurs by inhalation of infectious droplet nuclei containing viable bacilli (aerosol spread). Factors influencing the chance of transmission include the bacillary load of the source case, e.g., higher transmission occurs from active pulmonary cases who are sputum smear-positive or who display lung cavities on a chest radiograph, as well as the proximity and duration of exposure [5]. Overall, the risk of infection among household contacts of TB patients is around 30\% [6]. Transmission is rapidly reduced with effective treatment [7]. Therefore, early TB diagnosis and management is critical.

An acid-fast bacilli (AFB) smear is used to screen for new TB infection, and this method requires fresh sputum from patients as input samples. Previous work 
in Brazil on the accuracy of the AFB smear method reported that this test has a sensitivity of $36 \%$ and a specificity of $100 \%$ [ 8$]$.

The conventional culture method for Mycobacterium tuberculosis is a more sensitive technique by which to detect TB compared with AFB smears, but, due to the slow growth of the organism, sputum cultures take 4-6 weeks to become positive on solid media and 10-21 days in liquid media. Solid culture is usually performed on Lowenstein-Jensen (LJ), Ogawa, or Middlebrook 7H10/11. Liquid culture of M. tuberculosis is more sensitive and rapid than solid culture but is prone to contamination in some laboratories, so it is best to use both methods in conjunction [9].

The significant advance in the diagnosis of TB in the last decade has been the advent of the Gene Xpert MTB/RIF (Gene Xpert) test. The accuracy of the Gene Xpert test offers a significant increase in terms of diagnostic sensitivity, even when it is deployed selectively, i.e., among only smear-negative presumptive TB patients. However, because this method is limited by the expensive equipment required, the Gene Xpert assay is still rarely used in countries with a high HIV/ TB prevalence [10].

The detection of $M$. tuberculosis in clinical samples is generally less sensitive than the detection of other pathogens due to the relatively low numbers of bacilli present [11]. Despite this limitation, the nucleic acid amplification method has the potential to be used for differentiating the species and strains of isolates and clinical specimens [12].

In Indonesia, new patient TB is initially diagnosed by the AFB smear and X-ray methods. Following positive results from these tests, the patient status is further monitored by the culture method during the treatment period. Traditional TB control focused on the identification and treatment of sputum smear-positive TB patients, who are considered the most infectious cases. In a policy change in 2010, the World Health Organization recommended that two sputum samples are sufficient, rather than the standard three samples (spot-morning-spot) that had been recommended for several decades [13]. Repeated testing may still be warranted, so it is important to establish a good diagnostic method for detecting active lung TB.

The methods for MTBC detection have variable accuracy, and a combination of serial tests is expected to increase the overall accuracy of the diagnostic method. Therefore, this study investigated the diagnostic quality of applying serial MTBC detection tests to detecting active lung TB in Indonesia.

\section{Main text}

\section{Methods}

This study was conducted on sputum samples from pulmonary TB patients. All samples were examined by serial tests: smear microscopy, culture method, Gene Xpert assay, and PCR assay. All methods were used to evaluate the sensitivity and specificity for detecting active TB.

\section{Patients}

From September to December 2016, sputum samples were collected 96 samples by random sampling which collected from minimum representative samples of pulmonary active TB patients with positive and negative AFB results, who were either untreated or treated with anti-TB drugs, in the Dr. Soetomo Academic Hospital, Surabaya, Indonesia. These samples were then examined using smear microscopy, culture, PCR, and the Gene Xpert assay. The Gene Xpert assay was used for the screening of antibiotic-resistant cases. For each patient, the sex (male or female), age group $(<30$ years old; $30-60$ years old; or $>60$ years old), and length of drug treatment ( $<6$ months or $>6$ months) were recorded.

\section{Smear microscopy}

The sputum samples were first decontaminated with $4 \%$ $\mathrm{NaOH}$ as previously described [14]. After decontamination, a circular smear of each sputum sample was made on slides with a $2 \times 3-\mathrm{cm}^{2}$ surface area. For the AFB smears, the Ziehl-Neelsen staining method was used as previously described $[15,16]$.

\section{Mycobacterial culture}

The culture method was performed using LowensteinJensen and Middlebrook media (Merck, Germany) [17]. This method requires around 3-4 weeks for visible colonies to grow. After the colonies appeared, they were subjected to the SD Bioline MPT64 antigen test (Standard Diagnostic, Germany) to identify the MTBC species.

\section{DNA extraction}

DNA extraction was conducted using the Qiagen DNA extraction kit (DNeasy ${ }^{\circledR}$, Cat. No. 69504). Extracted DNA was amplified using PCR (MJ MiniTM Thermal cycle, BioRed). The primers used were F: 5'-CGC GCT TTT GTT TGG AGA GTT TGA TCC TGG-3' and R: 5'-GAG AAA GGA GAT CCA GCC GC-3'. These primers were designed using the genetic program MTBC H37Rv ATCC 27294 with a 1537-bp specific region on the MTBC $16 \mathrm{~S}$ rRNA gene as a target. The primers were added to the PCR Mix (KapaBiosystem ${ }^{\circledR}$ Ready Mix). 


\section{PCR amplification}

Amplification was initiated with denaturation at $94{ }^{\circ} \mathrm{C}$ for $20 \mathrm{~s}$, followed by annealing at $53.8^{\circ} \mathrm{C}$ for $10 \mathrm{~s}$, and extension at $72{ }^{\circ} \mathrm{C}$ for $30 \mathrm{~s}$ [16]. The PCR results were visualized using electrophoresis followed by UV transillumination. The $16 \mathrm{~S}$ rRNA gene of $M$. tuberculosis H37Rv strain ATCC 27294 was used as a positive control, and PCR mix (KapaBiosystem ${ }^{\circledR}$ Ready Mix) without DNA was used as a negative control.

\section{Gene Xpert}

The Gene Xpert MTB/RIF test (Cepheid, CA, USA) was performed in the Department of Clinical Microbiology, Dr. Soetomo Academic Hospital in accordance with the standardized procedure provided in the accompanying manual [18].

\section{Statistical analysis}

The sensitivity and specificity of serial tests for TB detection were conducted by applying the culture method as the Gold Standard and performing $t$-tests in a $2 \times 2$ table analysis.

\section{Results}

We obtained sputum samples from 96 pulmonary TB patients in Indonesia. These patients included 56 men (58.33\%) and 40 women (41.67\%). Most of the patients were aged around $30-60$ years old (78.13\%), and most of the patients had a drug treatment history of less than 6 months (89.6\%).

All the samples were tested using AFB smears, the culture method, Gene Xpert assays, and nucleic acid amplification. The sensitivity of these serial tests was calculated based on the culture method as the Gold Standard. Samples with negative AFB smear results were often positively detected using a nucleic amplification test, with a sensitivity of $83.1 \%$. The positivity result of PCR in negative AFB smear same with Gene Xpert (Table 1). On the other hand, negative culture result can be detected by PCR until 50 samples with specificity $79.17 \%$. Furthermore, the amplification of nucleic acid similarly yielded positive results for samples that had negative culture results. These joint results were comparable to the Gene Xpert results.

\section{Discussion}

The AFB smear detects all acid-fast bacilli, including Mycobacterium tuberculosis and Non-Tuberculous Mycobacteria (NTM), it makes AFB smear not specific. Centrifugation and filtration can increase the concentration of sample to improve sensitivity of AFB smear [19], although there is AFB smear without concentration which is used and can cause many limitations.

\begin{tabular}{|c|c|c|c|}
\hline & \multicolumn{2}{|l|}{ PCR } & \multirow[t]{2}{*}{ Comparison } \\
\hline & Positive & Negative & \\
\hline \multicolumn{4}{|l|}{ AFB } \\
\hline Positive & 59 & 20 & Sensitivity: $83.1 \%$ \\
\hline Negative & 12 & 5 & Specificity: 20\% \\
\hline \multicolumn{4}{|l|}{ Gene Xpert } \\
\hline Positive & 59 & 21 & Sensitivity: $63.64 \%$ \\
\hline Negative & 12 & 4 & Specificity: 16.67\% \\
\hline \multicolumn{4}{|l|}{ Culture } \\
\hline Positive & 22 & 5 & Sensitivity: $30.56 \%$ \\
\hline Negative & 50 & 19 & Specificity: $79.17 \%$ \\
\hline
\end{tabular}

Italic indicates the majority of samples

Additionally, this method still has low sensitivity for confirming MTBC infection [20]. Notably, a single AFB-positive sputum smear is now considered sufficient for a TB diagnosis [21, 22].

The culture method is necessary to confirm drug susceptibility, particularly for second-line drugs in cases of multi-drug resistance (i.e., MDR TB). The application of $M$. tuberculosis culture and phenotypic drug susceptibility testing (DST) requires significant training, infrastructure, strict infection control, and on-going quality assurance; however, in most countries, these are available in only regional reference laboratories. In this study, results based on only the culture method showed low positivity, which could be due to the requirements of this method for appropriate media, proper technique, and high quality specimens. Before the culture method was performed, the specimens were decontaminated, which required careful handling because a $\mathrm{NaOH}$ concentration that is too high will kill the bacteria but one that is too low will allow sample contamination [23]. Other study said culture is still as Gold standard for diagnosis of $\mathrm{TB}$, but it is more difficult and may not be available, this method also required as much as $6-8$ weeks to collect the result [24].

In the present study, they found $6.6 \%$ of rifampicin resistant strains (DST proven) revealing no mutations of rifampicin in the RRDR of $r p o B$ gene in Gene Xpert assay, even if has a specific cartridge that was developed to simultaneously detect $M$. tuberculosis and determine its resistance to rifampicin [25, 26]. However, many of the patients diagnosed based on Gene Xpert assay results would also have been appropriately diagnosed based on chest X-ray findings or on clinical findings consistent with $\mathrm{TB}$, and the extent to which the use of the Gene Xpert assay will increase the number of detected TB cases is not yet clear. Theoretical studies 
suggest that the application of this test will improve treatment targeting, with fewer patients who do not have TB incorrectly started on anti-TB treatment and a greater number of smear-negative "true TB" cases detected [27].

Nucleic acid amplification tests (NAAT), in which the most important one is the polymerase chain reaction (PCR), have emerged as powerful tools for rapid detection of the mycobacteria in clinical and research specimens [24]. The PCR method applied in this study used the 16S rRNA gene. Although both are molecular methods, this test is distinct from the method used by the Gene Xpert assay. Notably, the PCR method can identify cases of pulmonary TB infection from sputum samples more specifically compared with the other available methods [28]. The 16S rRNA gene is a universal gene in bacteria; this gene is functional and contains both a conserved region and a variable region [29]. Methods using this target gene allow the specific design of primers for the MTBC $16 \mathrm{~S}$ rRNA gene; thus, only cases with MTBC infection yield positive results.

Some of the results obtained by other methods are not same as that by PCR because of the weakness of each method, so the serial test is important to determine and to distinguish the pulmonary TB infection from other diseases. Notably, it is best to apply all these methods as TB diagnostic tests before anti-TB drug treatment is begun [30]. In Indonesia, the diagnosis of new TB cases typically still occurs without the application of the Gene Xpert or PCR methods, although the Gene Xpert assay is used in Indonesia to confirm active TB in drug-resistant cases.

In conclusion, the application of serial tests as a new algorithm for MTBC detection can increase the validity of the TB diagnostic method, and this will better guide the management of TB treatment. The previous algorithm consists of AFB smear, culture method, and nucleic acid amplification test [31]. Our results provide a good comparison among methods, improve and indicate that the use of serial detection tests can identify cases that might otherwise fail to be detected.

\section{Limitations}

This is the first study to investigate the molecular detection using a gene region that could be used to identify active TB cases but is insufficient for other uses, i.e., detecting the drug resistance of TB.

\section{Abbreviations}

TB: tuberculosis; MTBC: Mycobacterium tuberculosis complex; AFB: acid fast bacilli; NTM: non-tuberculous Mycobacteria; LJ: Lowenstein-Jensen; PCR: polymerase chain reaction; DST: drug susceptibility testing.

\section{Acknowledgements}

This research was partly supported by the Institute of Tropical Disease, Universitas Airlangga; Faculty of Medicine, Universitas Airlangga; Dr. Soetomo General Hospital, Surabaya Indonesia; and Department of Microbiology, Kyoto University. The authors would like to acknowledge support from several laboratory technicians, namely Agnes Dwi Sis P from the Tuberculosis laboratory and Sugeng Harijono, Catur Endra Kurnia A., Hanik Urifah, and Jayanti Pratiwi Hariyanto Putri from the Department of Clinical Microbiology, for collecting sputum and examining the culture method results. The authors would also like to thank Katie Oakley, Ph.D., from Edanz Group (www.edanzediting.com/ ac) for editing a draft of this manuscript.

\section{Authors' contributions}

NIPS: lead the research, designed the study, and made substantial contributions to the data conception, collection, and analysis as well as the manuscript drafting and revision (based on suggestions from the other authors). NMM: lead the research and contributed to funding acquisition, study design, manuscript drafting, and intellectual content revision. S: contributed to manuscript revision and intellectual content. FM: contributed to study design, manuscript revision, and data analysis. All authors read and approved the final manuscript.

\section{Funding}

This research was funded by the Directorate General of Higher Education, Ministry of Research Technology and the High Education Republic of Indonesia (Grant Number 01/E/KPT/2017) in design study, collection, analysis; and was partly supported by the Japan Agency for Medical Research and Development Japan program (AMED: 19fk0108043h0203) in interpretation of data, writing the manuscript, and English editing.

\section{Availability of data and materials}

The data set from the current study is available upon request from the corresponding author.

\section{Ethics approval and consent to participate}

All the patients who participated in this research signed an informed consent form that clearly stated the purpose of the research, the method of sample collection, and the lack of risk from medical procedures. They also received an agreement form and resignation form. This research was granted ethical clearance approved by the Ethical Committee in Health Research Unit of Dr. Soetomo General Hospital Surabaya, Indonesia (no. 537/Panke. KKE/IX/2016).

\section{Consent for publication}

Not applicable.

\section{Competing interests}

The authors declare that they have no competing interests.

\section{Author details}

${ }^{1}$ Doctoral Program of Medical Science, Faculty of Medicine, Universitas Airlangga, J. Mayjen. Prof. Dr. Moestopo No. 47, Surabaya 60131, Indonesia. ${ }^{2}$ Department of Clinical Microbiology, Faculty of Medicine, Universitas Airlangga, J. Mayjen. Prof. Dr. Moestopo No. 47, Surabaya 60131, Indonesia. ${ }^{3}$ Laboratory of Tuberculosis, Institute of Tropical Disease, Universitas Airlangga, Kampus C, J. Mulyorejo, Surabaya 60115, Indonesia. ${ }^{4}$ Department of Pulmonology and Respiratory Medicine, Faculty of Medicine, Universitas Airlangga, J. Mayjen. Prof. Dr. Moestopo No. 47, Surabaya 60131, Indonesia. ${ }^{5}$ Department of Microbiology, Graduate School of Medicine, Kyoto University, Kyoto, Japan.

Received: 26 February 2019 Accepted: 29 May 2019

Published online: 03 June 2019

References

1. Paulson T. Epidemiology: a mortal foe. Nature. 2013;502(7470):S2-3.

2. World Health Organization. Global tuberculosis report 2015. 20th ed. Switzerland: WHO Press; 2015.

3. Cloud JL, Neal H, Rosenberry R, Turenne CY, Jama M, Hillyard DR, Carroll KC. Identification of Mycobacterium spp. by using a commercial $16 \mathrm{~S}$ ribosomal DNA sequencing kit and additional sequencing libraries. J Clin Microbiol. 2002;40:400-6. 
4. Tille P. Bailey \& Scott's diagnostic microbiology. 13th ed. Beijing: Elsevier Mosby; 2014.

5. Escombe AR, Moore DAJ, Gilman RH, Pan W, Navincopa M, Ticona E, Martınez C, Caviedes L, Sheen P, Gonzalez A, Noakes CJ, Friedland JS, Evans CA. The infectiousness of tuberculosis patients coinfected with HIV. PLoS Med. 2008;5(9):e188.

6. Singh M, Mynak ML, Kumar L, Mathew JL, Jindal SK. Prevalence and risk factors for transmission of infection among children in household contact with adults having pulmonary tuberculosis. Arch Dis Child. 2005;90:624-8.

7. Dharmadhikari AS, Mphahlele M, Venter K, Stoltz A, Mathebula R, Masotla T, van der Walt M, Pagano M, Jensen P, Nardell E. Rapid impact of effective treatment on transmission of multidrug-resistant tuberculosis. Int J Tuberc Lung Dis. 2014;18(9):1019-25.

8. Conde MB, Soares SLM, Mello FCQ, Rezende VM, Almeida LL, Reingold AL, Daley CL, Kritski AL. Comparison of sputum induction with fiberoptic bronchoscopy in the diagnosis of tuberculosis. experience at an acquired immune deficiency syndrome reference center in Rio de Janeiro, Brazil. Am J Respir Crit Care Med. 2000;162:2238-40.

9. Lawson L, Emenyonu N, Abdurrahman ST, Lawson JO, Uzoewulu GN, Sogaolu OM, Ebisike JN, Parry CM, Yassin MA, Cuevas LE. Comparison of Mycobacterium tuberculosis drug susceptibility using solid and liquid culture in Nigeria. BMC Res Notes. 2013;6:215.

10. Muttamba W, Ssengooba W, Sekibira R, Kirenga B, Katamba A, Joloba M. Accuracy of different Xpert MTB/Rif implementation strategies in programmatic settings at the regional referral hospitals in Uganda: evidence for countrywide roll out. PLoS ONE. 2018;13(3):e0194741.

11. Heemskerk D, Caws M, Marais B, Farrar J. Tuberculosis in adults and children. Switzerland: Springer International Publishing; 2015.

12. Kazumi Y, Mitarai $S$. The evaluation of an identification algorithm for Mycobacterium species using the $16 \mathrm{~S}$ rRNA coding gene and rpoB. Int J Mycobacteriol. 2012;1:21-8.

13. World Health Organisation. Same day diagnosis of tuberculosis by microscopy: policy statement. Geneva: World Health Organisation; 2010

14. Chatterjee M, Bhattacharya S, Karak K, Dastidar SG. Effects of different methods of decontamination for successful cultivation of Mycobacterium tuberculosis. Indian J Med Respir. 2013;138(4):541-8.

15. Datta K. Scilogs. www.scilogs.com. Accessed 5 Dec 2013.

16. Global Laboratory Initiative TB diagnosis. Mycobacteriology laboratory manual. 1st ed. Japan: Otsuka; 2014

17. Sari NIP, Juniastuti WT, Artama NM, Mertaniasih. Bacteria confirmation using detection of specific 165 rRNA gene of Mycobacterium tuberculosis complex in sputum specimen for pulmonary TB. In: Proceeding of the 7th annual basic science international conference; 2017. vol. 3, p. 79-81.
18. World Health Organization. Xpert MTB/RIF-rapid TB test, WHO publishes policy and guidance for implementers. Geneva: World Health Organization: 2011.

19. Deun AV, Maug AKJ, Salim MAH, Das PK, Sarker MR, Daru P, Rieder HL. Short, highly effective, and inexpensive standardized treatment of multidrug-resistant tuberculosis. Am J Respir Crit Care Med. 2010;182:684-92.

20. Mertaniasih NM, Koendhori EB, Kusumaningrum D. Tuberculosis diagnostic microbiologist. Surabaya: Airlangga University Press; 2013.

21. Bonner M, Ramsay A, Gagnidze L, Githui W, Guerin PJ, Varaine F. Reducing the number of sputum samples examined and thresholds for positivity: an opportunity to optimize smear microscopy. Int J Tuberc Lung Dis. 2007;11(9):953-8.

22. Mase SR, Ramsay A, Ng V, Henry M, Hopewell PC, Cunningham J, Urbanczik R, Perkins MD, Aziz MA, Pai M. Yield of serial sputum specimen examinations in the diagnosis of pulmonary tuberculosis: a systematic review. Int J Tuberc Lung Dis. 2007;11(5):485-95.

23. Chatterjee M, Bhattacharya S, Karak K, Dastidar SG. Effects of different methods of decontamination for successful cultivation of Mycobacterium tuberculosis. Indian J Med Res. 2013;138(4):541.

24. Vasconcelos-Santos DV, Zierhut M, Rao NA. Strengths and weaknesses of diagnostic tools for tuberculous uveitis. Ocul Immunol Inflamm. 2009;17(5):351-5.

25. Lawn SD, Nicol MP. Xpert ${ }^{\circledR}$ MTB/RIF assay: development, evaluation and implementation of a new rapid molecular diagnostic for tuberculosis and rifampicin resistance. Future Microbiol. 2011;6(9):1067-82.

26. Patra SK, Jain A, Sherwal BL, Khanna A. Rapid detection of mutation in RRDR of rpo $B$ gene for rifampicin resistance in MDR-pulmonary tuberculosis by DNA sequencing. Ind J Clin Biochem. 2010;25(3):315-8.

27. Steingart KR, Sohn H, Schiller I, Kloda LA, Boehme CC, Pai M, Dendukuri N. Xpert ${ }^{\circledR}$ Mtb/Rif assay for pulmonary tuberculosis and rifampicin resistance in adults. Cochrane Database Syst Rev. 2013;31(1):1-131.

28. Eddabra R, Benhassou HA. Rapid molecular assays for detection of tuberculosis. Pneumonia (Nathan). 2018;10:4.

29. Tamarin RH. Principles of genetics. Boston: McGraw-Hill Companies Inc; 2002.

30. Ryu YJ. Diagnosis of pulmonary tuberculosis: recent advances and diagnostic algorithms. Tuberc Respir Dis. 2015;78:64-71.

31. Heemskerk D, Caws M, Marais B, Farrar J. Tuberculosis in adults and childern. Switzerland: Springer Briefs in Public Health; 2015

\section{Publisher's Note}

Springer Nature remains neutral with regard to jurisdictional claims in published maps and institutional affiliations.
Ready to submit your research? Choose BMC and benefit from:

- fast, convenient online submission

- thorough peer review by experienced researchers in your field

- rapid publication on acceptance

- support for research data, including large and complex data types

- gold Open Access which fosters wider collaboration and increased citations

- maximum visibility for your research: over $100 \mathrm{M}$ website views per year

At BMC, research is always in progress.

Learn more biomedcentral.com/submissions 